\title{
Research on the Application of Fair Value in Financial Accounting
}

\author{
Xiaoying $\mathrm{Li}^{1 \text {, a }}$ \\ ${ }^{1}$ Pennsylvania State University, 201 Old Main, University Park, Pennsylvania, United States, 16802 \\ a email:
}

Keywords: Financial Accounting, Fair Value, Theoretical Discussion, Accounting Application

\begin{abstract}
The application of fair value in financial accounting not only contributes to enhancing the transparency of financial accounting report, but also can effectively reflect the real business of the company or the investment situation. This paper attempts to explore the application of fair value in financial accounting from the fundamental nature and characteristics of financial accounting. According to the theory of corporate finance and accounting, it is necessary to face the position and application of fair value in financial accounting. Adhering to the system of financial accounting, this article comprehensively analyzes judgment, important function, logical relationship and reliability of fair value in order to put forward some countermeasures and suggestions for the use of fair value in financial accounting.
\end{abstract}

\section{Introduction}

After the outbreak of the international financial crisis, the companies and financial institutions have invested more energy in the measurement, accounting and research of fair value. At present, the fair value of the financial accounting in China is not flexible enough, and still maintains the traditional financial accounting functions and characteristics, which can not be adapted to the development trend of the company's financial accounting. In the new period, financial accounting not only need adhere to the combination of theory and practice, but also need explore the development logic, using fair value in company's financial accounting to meet the needs of the community's external investors.

\section{The Judgment Basis to Adopt Fair Value in Financial Accounting}

In the actual operation of financial accounting, it is required to adhere to certain judgment basis and operating principle. The correct judgment and estimation of the fair value in financial accounting can reduce the uncertainty to the lowest level in financial accounting to form the financial accounting report with a strong authenticity and the side effects of financial accounting reports. In order to ensure the fair value proposition to effectively recognized, it needs to make the data verify the contact and communication to take an orderly way and manner. The use of fair value in financial accounting can predict the future development trend of the company's business. The principle of historical cost accounting can effectively and truly reflect the history of the company's economic activities, therefore, the financial accounting report can not effectively predict the future development trend of the company and effectively predict the external development of the economic environment changes, it can only provide a certain financial accounting information. It is generally believed that the fair value in the field of financial accounting analysis can produce a certain impact on the company's financial accounting report. However, under the current popular accounting model, once the measurement activities carried out deviating from the main body of 
financial accounting, it will not truly reflect the company's economic operation. Because the various theories of fair value in financial accounting is based on the assumption of financial accounting. For the fair value of financial accounting, it is considered to be the important foundation and premise of the market. For the use of fair value in financial accounting, especially the changing in the process of holding financial assets, any proceeds from its production can not be recognized as a condition.

During the asset holding period of adopting a fair value in financial accounting, the company's earnings are likely to disrupt financial accounting statements and there is a certain logic relationship between the two aspects. Because the fair value of financial accounting is specifically referred to the estimated value of a certain time node, it may hide a certain risk and a lot of uncertainty factors in this time. For the measurement of fair value, it is generally considered unless the case of two changes occurred, it can confirm the revenue during the period.

\section{The Theories to Adopt Fair Value in Financial Accounting}

The use of fair value in financial accounting has a more profound theoretical basis and practical background, and the disadvantages of various information asymmetry in the traditional financial accounting are also gradually being recognized by everyone. Especially in recent years, with the rapid and healthy development of the market economy, the main body of accounting is facing the increasingly complicated market changes, therefore, the use of fair value in financial accounting is one of the most important tasks in front of the modern company, which is the most realistic problem of the company's further development. At the same time, some of the company's assets or liabilities of the fixed project have been changed because of market prices, in this case, if the fair value can be used in the financial statements, it can effectively affect the external stakeholders of the final decision. The recognition and recognition of the fair value at the theoretical level is due to a large number of financial risks brought by numerous financial derivatives since the financial crisis broke out.

For the use of fair value in financial accounting, it has a more profound connotation and extension, but this situation is different from the economic and social development in different regions because of the implementation of an accounting standard. Regardless of circumstances, the fair value in the financial accounting is based on certain assumptions and assumptions. This way is also more in line with internationally accepted accounting standards. For the fair value, from the internationally accepted definition, the scope of its definition is more extensive, which is not only limited to the concept of measurement attributes but has become a key link and important basis for the formation of other financial accounting attributes. From the point of strict sense view, adopting fair value in financial accounting can be used as a measurement attribute, at the same time, the fair value is abstract, so it is not suitable to be used as the attribute of financial accounting. Some experts and scholars believe that some financial accounting measurement attributes can be fully displayed through the fair value, and the fair value of financial accounting can also measure the quality characteristics and characteristics of other aspects of the measurement attributes. From a broader range, the use of fair value in financial accounting can also cover many measurement attributes. From the essence of the company's financial accounting, the company's financial accounting needs to reflect the company's economic operation, in particular, it needs to reflect the real situation of the company's transactions, so the fair value resulting from this should be concerned about the interests of the company, which is also the internal and essential requirements of the financial accounting functions. From a relatively narrow sense, the use of fair value in financial accounting is an important aspect of measurement attributes, and it can effectively reflect the market price and the trend of simulation. 


\section{Opposition and Unification Adopting Fair Value in Financial Accounting}

It is not absolutely correct to adopt a fair value in financial accounting, because the fair value has its own development of the limitations. However, the use of fair value in financial accounting has a strong advantage in the theoretical level, at the same time, we should also see that there are some defects in the use of fair value in financial accounting.From the perspective of financial accounting information, financial accounting information can affect the project investors to profit expectations, even can affect the investor's assessment of the company's business development and value. The fair value of the company can realistically reflect the company's current assets and elements of information and other aspects of information through the company's financial accounting statements. But it lacks the overall fair information, so it can be seen that the fair value in financial accounting can reflect the relative value of the company.Some assets, such as human resources, customer relationship and brand image can not be effectively reflected by the fair value. It can be seen in the next period of time, the use of fair value in financial accounting is not able to complete an accurate reflection of the company all kinds of changes in the value of accurate information, which will produce a certain information asymmetry.

The use of fair value in financial accounting is opposite and unified. Its historical cost is recognized as one of the most important measurement attributes in the field of financial accounting. In the case of a reasonable market transactions, it will not generate a range of values because of the great changes in the value of the company to further ensure that the company's financial accounting information is relatively reliable and scientific. The use of fair value and fair value in financial accounting pays more attention to the dynamic change of company value. For example, the transaction or business of the company has not been effectively carried out, but as long as there is enough evidence to show that some assets of the company can be able to follow the changes in the value of the market, the financial accounting will be displayed and reflected in a way. No matter what the situation is, it is valuable to reflect the company's real operating conditions, and then to achieve the fair value in the company's theoretical level through different angles to find a new relatively fair and reasonable price bottom line.

\section{Conclusion}

The use of fair value in financial accounting has always been a hot topic in the field of academic research, and there also has some controversy. Combined with practical experience, from the perspective of theory, this paper analyzes some issues using the fair value measurement in financial accounting. It can be seen that the use of fair value in financial accounting although has both advantages and disadvantages, the fair value is conducive to effectively solve some difficulties and problems in the financial accounting operation, so in the future financial accounting, it can be used to achieve a wider range of applications. The use of fair value in financial accounting has a great role in promoting the further development of financial accounting, therefore, it should pay research to actively explore deeper theoretical issues

\section{References}

[1] Ge Jiashu. Research on fair value accounting -- on the essential characteristics of financial accounting [J]. accounting research, 2009,05:6-13+96.

[2] Ge Jiashu. Discussion on the use of fair value in financial accounting [J]. Accounting research, 2007,11:3-8+95.

[3] Ren Zuotian, Chen Ci. Comparison of the fair value of financial accounting and tax accounting 
and their mutual reference [J]. Financial review, 2011,02:92-97.

[4] Xie Shifen, Dai Zili. Present value and fair value accounting: an important prerequisite for financial reform in twenty-first Century [J]. Theory and practice of Finance and economics, 2005,05:12-17.

[5] Chen Yong. Research on the theory and method of financial accounting under the concept of fair value [D]. Hunan University, 2005 